\title{
A Novel Motivation-based Conceptual Framework for Disengagement and De-radicalization Programs
}

\author{
Dounia Bouzar ${ }^{1,2}$ \\ ${ }^{1}$ Bouzar Expertises, France \\ ${ }^{2}$ Center for the Prevention of Islamic Sectoral Derivatives (CPDSI), France
}

Copyright $\mathrm{O} 2017$ by authors, all rights reserved. Authors agree that this article remains permanently open access under the terms of the Creative Commons Attribution License 4.0 International License

\begin{abstract}
From 2014 to 2016, the Centre de Prévention contre les Dérives Sectaires liées à l'Islam (CPDSI) was commissioned by the French Interior Ministry to establish the first indicators of radicalization, to come up with an experimental method for de-radicalization and to train law enforcement teams in France. A qualitative analysis of the data gathered from interviewing 809 young people prevented from joining ISIS, along with the collection of their interactions with the recruiters enabled us to identify the individualization of the recruitment pitches. Indeed, "the new radical discourse" adapts the jihadist ideology to the various emotional and cognitive needs of the young people, thereby pitching motivations tailored to their specific socio-culture and psychological profiles. The process analysis of the radicalization process sheds light on several sequential phases, which include a two-fold emotional-ideological dimension. This papers argues for a novel conceptual framework of the de-radicalizations studies and programs that take into account the link between the emotional and the ideological dimensions.
\end{abstract}

Keywords Jihad, De-radicalization, Disengagement, Adolescence, Motivation for Engagement, Emotional, Relational and Cognitive Dimensions, Recruitment

\section{Introduction}

Several studies have tried to tackle the etiology of radicalization that could lead to violence from the following risk factors: potentially underlying psychopathological disorders and personal vulnerabilities related to stigmatization and existential fragility [1]; a specific personality profile [2,3]; possible suicidal tendencies [4] among those involved in suicidal operations; psycho-social vulnerability analyzed in terms of group phenomena [5], and in relation to the historical and political context of the Arab World [6-8] ; the rationality or irrationality of the terrorist attack, viewed as cognitive distortion [9] and analyzed more broadly in terms of rationality determinants; and finally, possible identity tensions following from the radical discourse. It is generally accepted that there are no common features - apart from the young age and predominantly male gender - of those who become engaged in the radicalization process [10-12]: the educational backgrounds, financial resources, social statuses, motivations and reasons are always different $[13,14]$, as are the radicalization trajectories [15].

In 2014, the Islamic State in Iraq and the Levant (also known as the Islamic State in Iraq and Syria or ISIS) declared itself a caliphate, i.e., it created its own physical territory, which attracted a lot of young French recruits to join its ranks. In 2014, CPDSI was commissioned by the French government to study the radicalization phenomena, to train law enforcement professionals, and to support young people and their families who have been impacted by this problem. In August 2016, CPDSI published a report on the radicalization and de-radicalization process of the 1,134 youths they supported, including 809 "pro-jihadists" who were stopped before leaving to join ISIS, either by the police or their parents. Apart from the fact that most were minors or very young adults, another important feature of their social profiles became evident. Regardless of social class, recent immigration history in the family, or religion, the Islamist discourse seems to indiscriminately affect young people of both genders, and of different backgrounds.

The goal of this article is to share initial thoughts about, first, the relationship between the societal disengagement of these young people and their engagement in the radical narrative, and second, the more general need to study the engagement process and the underlying motivations in order to establish an adequate conceptual framework for disengagement.

\section{Methods and Objectives}

To tackle the process of engagement (and disengagement) of our sample, we qualitatively analyzed the motivations of 
809 young people whom we supported in their de-radicalization process. This analysis was done indirectly, on the basis of case-by-case interactions with CPDSI professionals who were responsible for monitoring these young people. The available materials comprised a collection of what was said during the sessions within the disengagement program. More specifically, the collection consisted of semi-structured individual interviews between the young people and their families, or therapy group sessions. In most cases, the multi-disciplinary team of CPDSI also had access to the recruit's interactions on social networks, on their computers, and/or phones, which was made possible thanks to the trusted relationship between the relatives of the young recruit and CPDSI. The videos that were exchanged during the recruitment were also used to better understand the recruit's sensitivity to propaganda.

Following a qualitative research method in social anthropology [16], we first immersed ourselves in the data, then we carried out a thematic analysis of the information gathered from the sample. This was done in order to study the phases of the radicalization process after having categorized the different reasons for engagement. CPDSI's intervention enabled to a large extent the use of a thematic qualitative analysis. Indeed, accessing the raw data enabled us to de-construct each individual pathway, both explicitly and implicitly. Most researchers and journalists can only study "jihadism" from testimonies of already radicalized individuals, by using either data from the Internet or interviews with these individuals after they have been incarcerated. In contrast, we had access to implicit data, i.e., to the ideals that the young people were fed during their radicalization (that is, elements they were not consciously aware of): we studied the conversations with the recruiters, their arguments, the videos they shared with the recruits, and also the young person's life history, their ideals before the radicalization, traumatic events they experienced and interviews with their relatives. In other words, we tried to collect data of everything that influenced the young person's engagement, assuming that "to be authoritative, discourse must make sense" [17]. It is essential to have access to multiple "invisible threads" in the jihadist radicalization process.

This requires a real effort since this is no longer just a problem of finding the "jihadist" archetype whose stigmata would be visible, hence marked and defined in advance. We propose to study the radicalization process of the individual. This approach, based on anthropology and informed by other social sciences (psychology, sociology, psychoanalysis, geopolitics, and history), has as its objective to study how the "radicalized" have come to embrace the "jihadist" ideology, and have changed their behaviors and worldviews during the radicalization process. We do not attempt to seek an explanation of the "jihadist" phenomenon or of the individual that had become jihadist, but rather to offer an understanding of their pathways.

We work with the premise of reconsidering the most basic presuppositions and to separate our work from the political and security discourse whose goal is to "control the enemy". At a time when French political discourse is focused on risks by certain groups of its population (immigrants, Muslims, "banlieues"), it is necessary to step back from what one would call "an embedded criminology" (an integrated criminology), a criminology constrained by politics while accepting presuppositions of security discourse as a postulate for scientific research. In contrast, in our role of "anti-jihadist practitioners", we start off from the field data to propose an autonomous analysis, which examines the social, cultural, geopolitical and psychological factors of the jihadist radicalization process. We assume that radicalization trajectory studies could help understand why an individual becomes engaged in this process, how he could disengage, and also what factors explain this evolution [18]. Studying the progressive process of engagement of 809 individuals will help us identify a certain number of sequential phases, and finally, would also allow us to outline the conceptual framework that guides the implementation of the disengagement strategies.

In another scientific study, in collaboration with Dr. David Cohen (Psychiatry of Child and Teenagers service of APHP Hospital of the Pitié-Salpétrière), we currently are trying to cross the characteristics of the youths' trajectories and their engagement motives, in order to identify recurrent models.

\section{Sample}

Our sample consists of 809 young people who participated in the CPDSI dis-indoctrination program from 2014 to 2016. These youths were stopped at the border either by law enforcement agencies or by their own parents. All were planning to go to a jihadist territory and all had a family member (a parent or a spouse) that had referred them to CPDSI for assistance (after CPDSI was appointed the main de-radicalization entity in France).

Working with 809 young people allowed CPDSI to identify the following 4 key points:

\subsection{The Family's Social Class}

From our interactions with the families and the prefecture professionals we learned that working class families were reluctant to report their child to the relevant authorities for fear that their siblings would become stigmatized or unable to find work. We believe that the social classes of the families referred to CPDSI are not representative of all families whose children were affected by this problem: $8 \%$ of the referrals came from the upper social class; $47 \%$ came from the middle class and $45 \%$ were from the working class. We speculate that the working class families were under-represented in this sample.

\subsection{Gender and Age}

Our sample included $64 \%$ young women. Based on our 
experience, we hypothesise that parents of young women are much quicker at noticing the signs of rupture that signal radicalization. The families of radicalized or radicalizing girls are thus referred to the authorities and are able to start the disengagement process much sooner.

The age group in the sample is between 15 and 25 years old. There were 4 girls aged 12 that tried joining ISIS three times.

\subsection{Self-declared Religious Faith}

Families that identified themselves as Muslim (24\%) were under-represented in this sample, since they, just like the working class families, do not trust the authorities enough to report their child to a law enforcement system they view as discriminatory or even racist. The families that identified themselves as Muslim had called the relevant authorities to seek help at a rather late stage in the radicalization of their child. More often it was the police who contacted the parents after having detected signs of radicalization, and at that time the family sought help for their child.

$44 \%$ of the families referred to CPDSI identified themselves as atheist, 30\% as Christian (Orthodox, Catholic or Protestant) and $2 \%$ as Jewish.

\subsection{Virtual Networks and Physical Networks}

All young recruits whose families referred them to CPDSI had used the Internet as a communications and sharing tool during the recruitment process. This does not mean there were not also physical networks. Indeed, the participation in a physical network could precede or happen along with the virtual communication.

The Internet enables recruiters to establish contact without disclosing their true identities. At first, they may look like a young person of similar age, or an expert, a teacher, etc. This allows them to get to know a wide range of young people and to better understand their profiles.

The term "recruiter" does not include only jihadists assigned by ISIS. Each recruit or would-be recruit becomes a recruiter, both consciously or unconsciously, insofar as he seeks to "awaken" those who do not see the "Truth," and to save them from the corrupt world.

\section{Results of the Engagement Process}

\subsection{A relational and Ideological Dimension}

By studying the conversations and the trajectories of the individuals in our sample, we established that radicalization includes a relational indoctrination and ideological indoctrination. The former means belonging to a new group, while the latter means belonging to a new way of thinking. There is a direct link between the two: the young person supports the new group if convinced it represents "true Islam" and vice versa: being convinced of representing "true Islam" is what connects the individual to their new group. In other words, beliefs influence behaviors and behaviors influence beliefs.

At some point, the jihadist narrative manages to transition the young person from his personal malaise (it being psychological or social) to supporting this narrative. Recruiters persuade the young person that supporting their ideology - represented as the only thing able to re-create the world-will take away his sense of ill-being. A cognitive link is established between the young person's experiences and the transcendental dimension of Islam. The young person evolves thus towards an ideology linked to collective identity. Nevertheless, the "religious" aspect is quite important in the jihadist radicalization: Islam is not only used as ideological justification, but it also presents itself as a narrative that gives life meaning and affords an opportunity to live in a group. To quote the French-American anthropologist Scott Atran, "The religious aspect is, of course, what unites the followers at the very beginning, but what they are really looking for is the strength of this bond" [19]. The relational — or even fusional — aspect is ubiquitous in both the jihadist pitch and in the recruit's needs. Scott Atran talks about "irrepressible need to create a compassionate core"[20]. This is indeed the sentiment expressed by all youths that we supported [21], namely, finding a group that met their needs of compassion and closeness. The relational aspect is the most difficult to combat in the disengagement process of adolescents. In this age group, the rupture from the group takes longer and is more painful than the deconstruction of the jihadist ideology.

Marc Sagement claims that $70 \%$ of the members of Al-Qaeda joined the organisation on the sole basis of friendships [22]. Yet, Al-Qaeda relied initially on a theological plan to gain support for their group. In contrast, we shall see that current recruiters rely primarily on intimate ties with the youths, as if they knew that relational indoctrination was quicker than ideological.

One may think that recruiters tend to rely more on the relational aspect when trying to engage women, and that women are more susceptible to promises of bonding with the radical group. However, we found no evidence for this hypothesis. The bond with the group is by no means stronger in women than in men. The quest for bonding with the radical group depends more on the vulnerability and the pre-radicalization profile of the person than on their gender [23].

Several techniques are used to strengthen the bond within the radical group. Adopting a kunya (nickname that refers to the descendants of the Prophet's companions) marks the rupture from the young person's old life and their rebirth in this allegedly sacred substitution group. Wearing clothes that conceal the physical identity of each individual (female and sometimes even male) signals the dissolution of the individual within the group: "When I see a sister wearing a niqab, I feel this is my 'other me'; we were all the same, we 
had the same feelings, we were united like the fingers of the hand."

Covering garments also give the feeling of invincibility. More specifically, the garments, combined with the feeling of fusion within the group, are what make the young people feel invincible. During her de-radicalization process, Hanane $^{1}$ gradually became aware of the fact that her niqab was related to her desire to hide her sensibility: "My niqab is not only protection, it's also strength. People can tell me whatever they want, nothing will reach me... This was not just a niqab, but rather 'we all were wearing a niqab.' I was convinced I would never be alone again. Now that I've lost my group, it's as if I've lost my protective shield."

These testimonies - selected as most representative - show that the relational aspect is at the heart of the support for the jihadist group. It's as if within this new virtual or real "tribe," the young people communicated amongst themselves better, could trust each other, felt understood, loved and protected. As Scott Atran said in an interview: "What always amazes me about the would-be suicide bombers is that they do not exude hatred (as most field observers would confirm) but - as horrible as it may sound - these people exude love. This analysis is almost impossible for us to understand, but we should make an effort at the risk of not understanding the phenomenon and thus letting it spread. Following tribal logic, we must consider the interior of the group, and we must talk about the need for compassion and intimacy rather than hatred and destruction." [24]

\subsection{An Anxiety-inducing Emotional Approach Adapted to Each Youth}

Jihadist recruiters want to create a feeling of fusion within the radical group in which it is the group that thinks and exists rather than the individual. To do that, they make use of an anxiety-inducing emotional approach tailored to the culture of each individual. Among the 809 youths that we supported, there were no cases of jihadist recruitment without the creation, at some point or another, distrust in the government institutions and adults in general. "Jihadist discourse" is intended to make the young person distrust the people around them. In his work, Gérard Bronner demonstrates that the essence of all aspects of social life rests upon trust among humans [25]. If we can live surrounded by other people, it is because we feel certain predictability in our collective life, and that the others' behaviour is similar to ours. The anxiety-inducing emotional approach wants to destroy this fundamental feeling and replace it with distrust in the people around us since they are apparently "sleepers" or "accomplices" of secret, powerful forces.

Jihadists make use of conspiracy theories to create stress, fear, distrust and suspicion. Several studies have shown that exposure to conspiracy narratives increases the feeling of

1 The name has been changed to conceal the identity of the young woman. uncertainty defined as follows: "Uncertainty occurs when people do not understand what has caused a situation they are in, how the factors currently within a situation are interacting, or how events will play out going forward." It has also been shown that this uncertainty is at the root of a quest for compensatory measures: "Experiencing emotions that reflect uncertainty about the world (e.g., worry, surprise, fear, hope), compared to certain emotions (e.g., anger, happiness, disgust, contentment), would activate the need to imbue the world with order and structure across a wide range of compensatory measures." [26] In other words, "explicit uncertainty significantly increased anxiety and urge to perform a safety behavior at low, but not at high, levels of threat" [27]. With this in mind, exposing young people to conspiracy narratives is, in itself, a stressful situation, which requires one to assess the following two factors: first, the threat itself, and second, the individual capabilities necessary to oppose it [28].

The young people that we supported all experienced the feeling that adults were allegedly sleepers or accomplices of some secret societies (mostly Illuminati) who conspire in order to keep power and technology for themselves, unbeknownst to the world. These secret societies allegedly disseminate subliminal images to prevent people from exercising their analytical abilities. Therefore, they claim, it is necessary to cut oneself off from others and from everything related to the surrounding culture so as not to be blinded in turn. In this way, young people would lose their confidence in government institutions, society, adults, and the entire world, all of which they would regard as corrupt. The goal of this anxiety-inducing emotional approach is to present the real world (family and friends, activities, society, etc.) as diverting the youth from "the truth," so that the jihadist group would become the only source for judgements, positive emotions and safe environments [28].

In this anxiety-inducing emotional approach, some recruiters first use videos that criticize the production system, while others use religious arguments. They want to make sure the resources they rely on would appear credible to their target audience, and will thus be able to influence their opinions.

In the first case, recruiters would initially share YouTube videos that would show the young person that all adults lie to them: this includes the food they eat, vaccines, medications, history, politics, etc. The next step is to send related links that show that these are not isolated lies. The secret societies, the Illuminati, funded by Israel, apparently want to keep science and liberty for themselves; they buy and control all governments; they invented HIV and Ebola viruses to kill as many people as possible; they place hormones in aircraft exhaust systems to stupefy whole populations; they pay the food industries and medical industries to make us eat harmful products, etc.

The young people shared with us that they watched video after video in the safety of their own rooms. The last step in the recruitment process was to warn them against the omnipresence of subliminal images: in advertisements, 
paintings, music, videos, etc. These images allegedly divert people from the only force able to fight them: the true Islam which belongs not to the sleeping masses of Muslims but to "the Truthful Ones," i.e., those who awoke and were granted the Truth. The recruiters accompany the young people during their rupture from the real world and they continue to make them feel valued: the previously experienced malaise (common to all teenagers) allegedly stemmed from the fact that they-unlike all around them-were chosen by God to tell the truth from the lie. This approach enables the recruiters to reverse a feeling of discomfort-commonly experienced by the youths and their relatives - into evidence of their superiority, that is, they felt discomfort because they were the chosen ones. They perceived the world as corrupt, while their friends lived without realizing it at all.

This first belief, which is not directly religious, has made the young person adopt a paranoid worldview that made them turn their backs on their friends and family. Norah, who attempted to leave for Syria twice at the age of 16, talks about how the feeling of being persecuted is directly related to the conviction of being chosen: "We knew we couldn't talk on the phone... So do we take out the SIM card? Or even the battery? It was obvious: our enemies were everywhere. Since we knew the truth, we were constantly under surveillance. And the more we felt under surveillance, the stronger became our conviction of knowing the truth. I saw this as belonging to an authentic group, in which we were the most "awakened" ones. We were being tracked because they wanted us asleep and indoctrinated... I was afraid that people were trying to lull me to sleep and to hurt me. I had to stay awake, no matter what." So Norah quickly breaks with her existing world: she stops going to college, she stops talking to her previous friends, she no longer maintains her hobbies, and she sees enemies in her parents [30].

The conspiracy theory and the sense of being persecuted can take on a sacred connotation. Things were similar for Rachid, with the exception that the conspiracy theory became authentic based on where it came from. Before joining his jihadist group, this young adult was not an Internet enthusiast. He used to meet a small group from his neighbourhood that would share video clips about the massacre of Muslims around the world. He was also immersed in the conspiracy theory as conveyed in the group's narrative: "When the brothers and the people of science $^{2}$ took up this theory, it took on a fundamental reading... It wasn't just a simple theory for a debate... This information was provided by the brothers in Afghanistan, on the field, or it came from a website created by the brothers. We very much respected these brothers. So by extension, we respected what they said."

Recruiters deliberately make this paranoid worldview appear sacred by mixing profane and sacred registers. Hanane is a practicing girl who wants to join ISIS, convinced

2 i.e., "who knew Islam well" that she should do her hijra. ${ }^{3}$ It all started with a conspiracy theory: "I remember a sheikh ${ }^{4}$ who constantly spoke about the end of the world... He read the news looking for signs of the end of the world, as they were declared in the Koran. But to prevent us from discussing his discourse, he would add hadiths here and there... In so doing, his discourse would be impossible to discuss or to question. Further, he would do the same thing about the conspiracy theory. When he spoke about the conspiracy theory, it was always presented from a religious point of view, which again made it impossible to question. One couldn't just tell him, 'Well, you understood that this way... or, where is the evidence?' In other words, if you questioned the conspiracy theory, it's as if you questioned the hadith that was cited with it... As a result, the conspiracy theory becomes almost as sacred as the hadith itself. At the end, you must believe in the conspiracy theory to be a good Muslim..." The conspiracy theory creates a sense of absolute distrust in any information that comes from outside the group in general, and from the media in particular.

The feeling of being persecuted is fundamental in the radicalization process: it even seems related to how dangerous a person is. A terrorist always feels in self-defence mode. Grégory explained how he went from wanting to save the children of Syria to wanting to kill all those who didn't help him save those kids: "I learned from the Internet that Bachar Al-Assad was massacring his people, and that, in the end, the international community had decided not to take any action. The more I watched videos about that, the more I wanted to be one of their saviours. I could only see injustice, nothing else. It is not the case that the recruiter you talk to is a guru. Rather, this is indoctrination without a guru. Falling for this ideology means breaking out on one's own from everyone else. Omar would only tell me things that would make me feel good and I would say to myself "That's what I thought." Still, I transitioned from wanting to save the Syrian children to being certain that the only solution was to fight against Bachar Al-Assad's army. I'm still unsure how I went from the idea of fighting against Bachar Al-Assad's army to wanting to eliminate everyone who didn't fight on my side! All these people, I considered Bachar's accomplices! At the end, we ended up being convinced that to defend Muslims, we had to kill everyone..."

Studying the recruiter-recruit conversations enabled us to analyze the religious arguments that underpinned the emotional anxiety-inducing approach. Religious arguments get exploited much sooner in the radicalization process for people from Muslim families. The most common example is related to the concepts of tawhid (oneness of God) and of shirk (to place someone at the same level as God, thus

3 The Islamic prophet immigrated to Medina to flee the persecution of Arabs in Mecca. This is what is called "hijra." In their narratives, fundamentalists use persecutions of Muslims in the world to convince young people to immigrate to Iraq or Syria to join ISIS, the only place where they can live their Islam.

4 Religious scholar 
committing the sin of idolatry). This transformation of the principle of the oneness of God into a concept so restrictive that it becomes a daily source of anxiety originates with various pietistic Salafist ideas. These ultimately deprive the individual of all the sensations and relationships which define the human experience. For example, listening to music would be considered equivalent to placing the musician as a creator at the same level as God, thus violating the principle of tawhid and "committing shirk." Following the same logic, appreciating an image would be the equivalent of regarding the artist as being at the same level as God. This threat of "committing shirk" is viewed in very general terms. The young people described how this anxiety swamps people in every facet of their lives. They cannot appreciate a football match or a good movie for fear of seeing a football player or an actor who they would end up viewing as an icon... They can no longer use the word "adore," even to say they "adore chocolate," because this verb must be reserved solely for the adoration of God. They cannot love their country, whichever one it is, because it would constitute in their eyes "the greatest idol" that would keep them away from God's grace.

This anxiety of "committing shirk" becomes constant: paranoia reaches its maximum stage in an individual when the Salafist group explains to him that since the temptation to "adore" something else than God is everywhere, he can sin without even realizing it. The only solution is to "rectify your tawhid", which becomes the only theme addressed in religion classes. One must focus on it, if one does not want to succumb to the ubiquitous temptations of this polytheistic world. The young person cuts himself off from all non-Salafist people because he considers that they could be polytheists without him realizing it since they walk in the streets without "having rectified their tawhid" [31].

From this stems an obsessional anxiety that translates into behaviors which resemble phobia: an adolescent demands that his mother turn off the radio before getting into the car, destroys the statues and paintings in his parents' home, rips up the family photos, refuses to exchange SMS's which might contain emoticons, and generally regards all activities as having the potential to keep him away from God. The conversations of the young people in our sample show that inside the group, they had advised each other that in order to limit the threat of committing shirk, they mustn't enter just any store for fear that the radio may play a song; they mustn't go to tourist areas for fear of being photographed; they must make sure that no musician is playing at the metro before using it, etc. Certain withdrawal behaviors, traditionally known as "communitarian", are in fact related to this anxiety: Salafists prefer buying groceries at designated stores to stay safe from any potential music played at an ordinary store. Finally, the young person arrives at the last stage where he considers that even respecting civil laws would be the equivalent of placing government authorities at the same level as God. Once arriving at this point, he refuses to sign documents such as depositions, employment contracts, or even a contract for basic services such as electricity. In short, he refuses to make a deal or a contract with any person who is obeying civil laws.

Jihadists re-appropriate these Salafist interpretations on the oneness of God, even if, once in a combat zone, they do not necessarily put them into practice. For example, they release numerous images to promote their propaganda on the Internet, and use music to galvanize their soldiers. But in contrast to pietistic Salafists, jihadists believe they must not only protect themselves from temptations but they must also actively fight against polytheism by imposing divine law. To avoid going to hell, they must go into action. Not only must one not associate God with other deities, but before adoring God, one must also reject the other deities. It is not enough to pray to God to be monotheistic, but one must also get rid of all things that remain from the time of polytheism. One can only adore God if he rejects everything that is around Him here on Earth.

The main difference between Salafists and jihadists relates to the treatment of someone who does not enforce the law of God. For the Salafists, it is only a sin and not an act of apostasy. From their point of view, they can live in a country in which civil laws are enforced if there are no other good options available. They do not bear the responsibility of shirk because they are not part of the ruling body. Instead, they have simply to ignore the civil government, for example by refusing to participate in the elections of "unbelievers" and not sending their children to a school of "unbelievers".

For the jihadists, submitting to civil law is by itself an act of shirk: it is an act of apostasy that puts government officials at the level of God. In their view, a Muslim does not have the right to live in a country whose government does not enforce the law of God. If this is not the case, they are committing shirk, by allowing a human to decide what is allowed and what is forbidden. The governments are responsible for the hindrance to tawhid by making and enforcing civil laws. Thus it becomes acceptable to kill anyone who works for the State, especially military and police. Contemporary jihadists add a level of "shirk": staying in "a land of unbelievers" is equivalent to implicitly recognizing that civil law is superior to the law of God. Committing shirk is not only limited to appreciating a football player, a singer, a politician, a philosopher, or even a country. To respect tawhid, one must not submit to civil laws. For them, respecting tawhid is equivalent to blaming the citizens who accept living in a country that operates by civil law. "There are no innocents" is their favorite maxim: this way, they can call takfir (declare apostate) all those who submit to civil laws, including pietistic Salafists, whom they call Mourjis (Muslims who believe that faith is in one's heart, regardless of their sins). Any citizen who lives in a country where civil laws are enforced can thus be killed in the name of God, regardless of their religious beliefs, or their profession.

In other words, Salafists and jihadists appropriate the Muslim notions of tawhid and shirk to create anxiety in the young Muslim recruits or the converts who have only a 
minimal knowledge of Islam. Similarly to how conspiracy theories get exploited, the goal here is to cut the recruits off from their friends and family, and from society. However, Salafists and jihadists don't offer the same compensatory solution to the corrupt world. When young people were approached by pietistic Salafists, the solutions offered were auto-exclusion and immigration to a Muslim-dominant territory. In contrast, when approached by jihadist groups, enforcing divine law by means of jihad to recreate the world becomes the only way to escape hell. Approximately half of the young people we consulted were part of a pietistic Salafist group before joining a jihadist group.

\subsection{The Recruiters' Discourse Tailors Jihadist Ideology to the Youths' Emotional and Cognitive Aspirations}

Alongside relational indoctrination, there is varied cognitive indoctrination: the recruiters pitch several myths tailored to the different psycho-social profiles of the youths.

Indeed, we have identified seven primary motives for radical engagement [32]. All of them, in one way or another, fall under:

- the search for an ideal, be it an ideal self, world, partner, or community

- $\quad$ and/or the escape from the real world towards "another place" that is supposed to be better.

These motives for engagement have been designated by the term "myth" in the CPDSI report [33] to highlight how radical rhetoric harnesses the personal motivations of the youths in order to indoctrinate them. The terminology chosen to name these myths is, of course, metaphorical. It offers the advantage of evoking a psychological universe that seems very specific to each category of young person. These myths will be explained in the next section, distinguishing between explicit and implicit motives for engagement:

- The explicit motive consists of what the young person said during the sessions.

- The implicit motive consists of elements the young person is not necessarily conscious of and which fall under an interpretation by the CPDSI team based on the young person's exchanges with his parents, his history, his ideals before his radicalization, the traumatic events he has been through, the videos he has watched, and so on.

Some of these aspects often came to be associated with specific engagement motives.

\subsubsection{The "ISIS as Utopia" Myth: the First Motive for Engagement: the Quest for a Better world}

Many youths evoke their desire for "Hijra" when they justify their decision to leave for Iraq or Syria. If we only take into account their statements once they are there, we may believe that their departure is strictly linked to religious reasons. Indeed, the Hijra is a Muslim concept which evokes the immigration of the Prophet in order to flee religious persecution. Recruiters insist on the fact that all Muslims are persecuted in the Western world in general, and in France in particular. Their videos showcase discrimination against Muslims and quotes from French debates on the prohibition of the headscarf for mothers chaperoning school trips or at the university. Others add scenes of persecution of Muslims in other countries. In those edited videos, we always find a mix of registers: scientific and magical thinking, historical fact and political discourse, information and disinformation. The discourse relies on a set of theories and traditions that are so encompassing that each person is bound to find an element from their own thinking. Once the feeling of persecution is exacerbated, escape appears to be the only solution in order to protect oneself. All the youths that we accompanied testified: "I could not even breathe, as I had the feeling that France was such a nasty country..."; "It was an obsession: I needed to flee. My brain was fixed on that. Any means were acceptable as long as I could go away."; "While waiting to be sheltered, I avoided all contacts. I was not going to put up with anything anymore: people, landscapes, smells... My enemy was everywhere."

The Hijra is thus the explicit reason evoked by the youths once their cognitive process has been transformed. But we noticed that those attracted by this reason for leaving France share a common profile. They are very gentle youths who have always dreamed of a perfect world. Beyond the notion of Hijra, the recruiters make them believe that they are building an ideal society in which equality, fraternity and solidarity will rule. It is this plan above all which attracts them in an implicit manner. The youths are leaving for a utopia that we call "the ISIS as Utopia". Apart from liberty, the values pitched appear to be similar to the French Republic's values, to the point of confusion. The videos used to indoctrinate the youths under the ISIS as Utopia myth show men or women of all origins sharing the same meal and helping each other. But in their eyes, only the submission to divine law can allow the building of a social organization where these values are applied. We can legitimately ask ourselves whether the large proportion of young Frenchmen in ISIS ranks is linked to the difficulty of the Republic in keeping its promises. It may seem paradoxical, but many jihadists believed in republican values, or are the little sisters of those who believed in them. Those of North-African origin are clearly over-invested in the Republic's promise of equality, themselves coming from often-corrupted states. Furthermore, the discrepancy between theory and practice, never recognized by government officials, has been all the more brutal. When ISIS pitched to the recruits a goal of social justice and equality, explaining to them that only the law of Allah allows it, they were already half-convinced.

Many propaganda videos mix images of happy children holding balloons in carousels to scenes of rice distribution to poor people in rags. This shows that young parents join ISIS with their children. Such is the case of Sofia, who was a single mother pregnant with two young children. She was then convinced that the society built by ISIS relied on 
sharing: food, heating, and free healthcare: "I thought that there, nobody could be egoistical or mean because we were all submissive to God. Being afraid of God, it means never doing evil. I was truly relieved when leaving. I imagined a world of solidarity, for example 'Oh your son does not have a sweater. Take my son's since he's got two of them...' Furthermore, brothers had sent money to me for the trip. This proved their solidarity..."

We can find again the over-importance of Islam which stems from the principle that religion can run all facets of life because it has an answer to everything [34]. Religion is the path chosen to deal with all dimensions of life. Islam remains the exclusive source from which everything else is taken: education, healthcare, social organization, laws, etc. There exists here a failure to recognize a produced reality that would not fall in line with absolute divine Truth. No value is considered the result of human experience. This is the question of the subject: between sacred texts and society, is there a space for individuals, and what is this space? Between divine word and daily action that is inspired by it, how do humans develop themselves? The real must correspond to the sacred text, like a carbon copy. This type of statement leads to a symbolic confusion that links Islam to a political system, which in turn contributes to muddling the debate on these questions by presenting an essentialist image of Islam, of which we would not be able to deconstruct the presuppositions. According to these interpretations, going into politics is a proof of faith.

\subsection{2. "Mother Theresa" Myth: the Humanitarian Motive for Engagement}

We call the second myth "Mother Theresa": "Save the children gassed by Bashar al-Assad" is the explicit reason evoked by the youths, who can be either male or female. But we notice that they all had altruistic professional aspirations in the medical and/or counseling fields (nurses, social assistants, physicians, etc.) and felt the need to be useful. Often, they "displayed" this humanitarian engagement on their Twitter or Facebook accounts, by posting a photograph of their last volunteer camp during the previous summer, or by stating the subjects they are studying in school. One may wonder if recruiters target them through searching for keywords.

Recruiters make them watch unbearable videos showing the children gassed by the dictator Bashar al-Assad, provoking what James Jaspers calls "moral shock", 5 that is, such a realization of the suffering of the victims in the video that the jihadists' ideology appears to be the only way to make those massacres stop. There again, the ideology draws a large part of its impact from emotional mechanisms. The videos, which make the youths believe they will save the Syrians by committing themselves to the ideology, have been very efficient. Between two agonized children, a voice

5 Jasper, J. The Art of Moral Protest, Chicago, Chicago University Press, 1999 questions the youth and asks her how she can stay in her Western comfort. Emilie testifies: "They explained to me that my nursing studies lasted such a long time in France because, apparently, it was a way to extract money out of me, whereas in fact they would be able to train me in three months. I had to quickly make up my mind because otherwise, another sister would get this opportunity."

The best videos were created by Omar Omsen, a former criminal who became specialized in kidnapping teenagers for the former Al-Nosra network. He used real humanitarian videos and mixed extracts of them into his comments. The image of a father who does not want to let go of the body of his small daughter killed by a bomb has made many youths cry and once and for all decide to become engaged in order to prevent those massacres. When ISIS jihadists realized the efficiency of these videos, they also filmed themselves distributing rice and speaking on humanitarian topics, in parallel to their classic propaganda based on conquest and absolute power.

\subsubsection{The "Saviour" Myth: the Self-Sacrificial Motive for Engagement in order to Save One's Family from Hell}

"Dying on the holy land because the end of the world is coming soon" is the explicit reason evoked by the youths once their cognitive process is transformed. They adopt the jihadist discourse which indicates that all the signs of the end of the world are here and that dying in the land of Sham ${ }^{6}$ guarantees going to heaven. But during the de-radicalization sessions, one will notice that the individuals hooked by this myth have recently been confronted by the sudden disappearance of a close relative (accident, death, fast-acting and frightening serious diseases, etc). By dying, they hope to "intercede" for this relative whom they consider an unbeliever or a lost Muslim. In some cases they want to "join him". Suicidal feelings are never far for those youths who are looking for meaning in their lives. It is the case of Inès, barely 12 years old, who attempted to leave for Syria three times, convinced that she would be able to join her brother in paradise if she were to die there. The child doubted her physical ability to carry a Kalashnikov, given her low weight, and the recruiters promised her that she would be entitled to an explosive belt as soon as she arrived.

The videos used by the recruiters calmed her anxieties and her culpability in still being alive because they described an enchanting paradise. To access it, one has to respect many prohibitions. Gradually, Inès viewed video after video in which sheikhs cry and are on the verge of agony imagining the tortures that will be inflicted upon all those who are not "one with the Truth". A person who becomes aware of this Truth must convert, if that is not already done, and die in the land of Sham in order to intercede to God for those he loves. $\mathrm{He}$ has the responsibility of saving them despite themselves.

6 The Sham is the Land of the Levant, which contains Syria and Iraq. For Muslims, the final battle which will precede the end of the world will take place there. It is also there that the Mahdi, that is, the last successor of the Prophet, will appear to fight against the forces of evil. 
They will soon find each other in paradise, because the end of the world is near. One has to leave immediately, without hesitation and pack their bags straight away. This motive for engagement is often crossed with the coming of the end of the world, whose proof can be summed up by the concordance of several forewarning signs of the apocalypse, including the fact that the international community did not intervene when Bashar al-Assad gassed his own people.

The reason for sacrificing one's life is adapted to the country's specific social and cultural situation. The promise to save a family that is "untrue" is reserved for the youths brought up in a nuclear family culture, where the bonds between children and parents are extremely strong. The promise to join their lost or non-Muslim parents in paradise is offered as a compensation for the abandonment caused by their departure to join ISIS. Finally, the suffering due to the separation here on Earth is compensated for by the promise of going to heaven forever. It is a blessing in disguise reserved for those who hardened themselves and truly have faith. The recruiters understand this well and prepare it with subtlety in their videos. This motivation for engagement is typically Western, adapted to the lack of awareness in a nuclear family whose members are often very close. In the social context of sexual frustration in the Maghreb, recruiters insist on a much more traditional aspect: dying in jihad would allow access to 72 virgins. $^{7}$

\subsubsection{The Myth of the Sleeping Beauty: the Global-wedding Motive for Engagement}

We named the only myth exclusively pitched to girls by the recruiters as "Sleeping beauty" because "finding a husband who will never abandon them" is the explicit motive evoked by the young girls once their cognitive process is transformed. However, we note that they were all looking for protection because they all felt very vulnerable, psychologically and physically, depending on their path.

The recruiters succeeded in creating the illusion that the world of ISIS respects women. The sitar (which covers even the eyes) is pitched as a jewelry box that protects diamonds, an envelope for the body so efficient that it becomes real armor. The gender-segregated world is pitched as the protection model best adapted to be effective against the perversity of men. Marrying a hero who sacrifices himself to save the children gassed by Bashar al-Assad only furthers this feeling of invulnerability. Some of the young girls have suffered sexual abuse or an attempt for sexual abuse in their past, which was not discussed and not treated. Marriage is pitched as "the solution" to the entirety of their problems.

When she was 12 years old, Aline was cornered by three boys in the bathroom of her secondary school. They

7 Certain verses of the Koran and certain hadiths (tradition) evoke the presence of "pure beings" in paradise, and a traditional belief translates those evocations by "virgins who are waiting for men in paradise..." This belief has been recuperated by jihadists to encourage fighters to die. We evoke the figure of 70 or 72 to count those "houris". http://oumma.com/14876/houris-hommes-12. "touched" her and she never told anyone about it because her father had just suffered a heart attack. All her family members and teachers were focused on the health of her father, and Aline suppressed her aggression, to not feel sorry for herself. Two years went by before she finally talked to her mother about it. Three years later, Aline was 17 years old when we took charge of her. She wore the niqab as well as gloves. Hooked by the Sleeping beauty myth, she is completely under the influence of the young man she met on the Internet and who talks to her day and night. Only a discussion with a girl who survived ISIS managed to make her doubt the reality of her marriage plans. By listening to her testimony, Aline realizes that she does not know her virtual interlocutor. The mourning period for the bearded prince will be long, but the "niqab rehab" longer still. For many months, Aline panics greatly every time she attempts to replace her niqab by a jilbab (a similar article of clothing, except that the face can be seen a little). Transitioning from the jilbab to the hijab (simple headscarf which does not cover the body but only the hair) takes again many months. Aline must relearn to protect herself in other ways than this large black veil that hides her personal identity features and dissolves her identity within the group. Whenever anxiety strikes, her mother finds her in fetal position, wrapped in her sheet, in which she covers herself completely.

\subsubsection{The Lancelot Myth: the Fighting Motive for Engagement against a Dictator}

A specific video has been directed by recruiters in order to reach youths who feel they have the soul of a knight, which reuses the music from the Disney film "Pirates of the Caribbean" and stages "The Little Prince". "Killing the soldiers in Bashar al-Assad's army" is the explicit motive evoked by the youths once their cognitive process has been transformed, but during the de-radicalization procedure, we note that these youths have often been attracted by communities of adventuring men. They want to test their courage, to know if they are capable, if they are men. There is often an aspect of vengeance for the weak against the strong, in order to regain one's dignity. Videos and discourse which hook youths on this myth encourage a desire towards self-sacrifice for history and posterity, thus filling in for the absence of intervention by the international community to save the children gassed by the Syrian dictator. But "dying for the cause" appears as pretext. Listening to the testimonies of those who were hooked through this path, we get the impression that their "self-sacrifice" is related to their tribe. "Lancelot" does not want to die in order to save his family, but his new community. As Scott Atran [35] reminds us, "In a tribe, bonds are so strong that the price of life and death is not the same anymore". "Lancelot" evokes soldiers who throw themselves under a tank with a grenade not with the idea that they will make their homeland win the war, not for glory, not for a medal, but for their group of friends, which takes on, under certain aspects, the value of a family. We then discover that many youths engaged through this motive 
had previously applied for the army or the national police force, or dreamt about this sort of profession. Others were children of soldiers.

\subsubsection{The Myth of Zeus: the Motivation for Engaging in Regenerating the World}

The ones who are hooked by the myth of Zeus do not have the same ideal, even if they also leave to fight. "Imposing the Sharia on the entire world" as the only way to get rid of corruption is the explicit motive evoked by the youths once their cognitive process is transformed. However, during the de-radicalization process we noticed that this motive for engagement mainly affected youths who knew no limits, who have been taking part for a long time in risky behaviors (drag racing, unprotected sex, drug addiction, alcoholism, etc.), and who were seeking absolute power. The main question concerns one's limits: "can I do it, or will I break?" They do not submit to God but re-appropriate His authority for themselves in order to command others. Many educators compare this specific type of "radical youths" to "young drug addicts": no assimilation of the law in its symbolic aspect, search for immediate pleasure - ecstasy, frequent lack of a regimental father figure [37]. The "jihadist" discourse gives a justification for their quest for absolute power. Some videos stage ISIS shooting at point blank range those who did not submit, then resuscitating them, and killing them again. Fethi Benslama talks about delinquents who are ready to dignify their antisocial urges into heroic actions in service of a supreme cause: "The figure of the super-Muslim attracts the delinquents or those who wish to become one: they convert because they wish to become outlaws in the name of the law, a law that is supposed to stand above all other laws, through which they dignify their antisocial tendencies, sanctify their murderous urges. The super-Muslim seeks an enjoyment that we could call man-God incest, when a human pretends to be in the intermingling with his supposed creator to an extent where he can act in his name, become his mouth and his hands." [38] One of the youths we followed left the Muslim Brotherhood to join the Salafists because he considered that the former did not possess the Truth, and he then went from the Salafists to the jihadists for the same reason. In the end, he let go of the utopia pitched by the jihadists when he observed that they too did not possess... the Truth! He created another group with four "brothers", who believed themselves "above" ISIS and Al-Qaeda. This young convert has parted with the groups, but not yet with his motive for engagement.

\subsubsection{The Myth of the Fortress: the Purity Motive for Engagement}

A seventh motive for engagement named Fortress was identified by the CPDSI team in the months following the publication of the 2015 report [39]. The choice of this terminology is motivated by two arguments, observed in some boys and girls:
- Obsessions focused on sexual themes (heterosexual, homosexual, and even pedophile in a few cases). These obsessions, often not accepted, seem to overwhelm the youth, who is terrified the idea of giving in.

- The ideal sought concerns a "better self": the youth sees radical Islam as a setting that contains him and makes him safe, protecting him from his sexual obsessions.

The explicit motive for radical engagement is a quest for purity and even holiness, which signifies in an implicit way the quest for something to contain them, the ideal for their own self-being to transform their body into a "fortress" against unwanted sexual thoughts. Because questions regarding sex constitute an important part of adolescence, we asked ourselves whether the myth of the Fortress was characteristic of a separate motive for radical engagement, or if it was common to all indoctrinated youths. Although it cannot be denied that sexual urges are common to all, whether they are expressed or not, the distinctive feature of the youths indoctrinated under this motive is a quest for holiness that is very specific to them. Another argument in favor of the importance of sex in this motive for engagement is the former very suggestive appearance of these youths, which sometimes still shows when they try to leave the country (for example, a young woman dressed in leather obsessed with her desire to join ISIS). When religious rituals fail to regulate their urges as they imagined they would, death through martyrdom seems to be the only way out when faced with the impossibility of attaining this ideal self. This hypothesis is supported by their possession of videos of alternating paradoxical contents on their phones or laptops. Pornographic videos are mixed with kamikaze scenes, followed by very strict sermons promoting gender-segregation along with strict prohibitions regarding sexuality, followed by speeches exalting the benefits of heaven. Death through martyrdom becoming a viable solution could explain why many attack perpetrators frequent prostitutes or otherwise seek the company of several women in night clubs just days or weeks before committing an attack. ${ }^{8}$ Therefore, such social interactions are not necessarily feints or covers concealing their violent plans, but a behavioral purge before their planned deaths, as if the subject had a liberation from existence into the afterlife ahead of his mission, where none of the taboos here on earth would be forbidden anymore.

The author of the crimes at the Orlando night club in June 2016 could be an example of this category of radicalized young person. Indeed, on the basis of what was written in the media about him ${ }^{9}$ it appears that in the recent past, the individual had frequented night clubs and gay dating sites, therefore displaying possible homosexual tendencies. Moreover, it was revealed in the press that in front of his

8 http://www.courrierinternational.com/article/2014/09/04/violents-mais-pa s-devots

9 http://tempsreel nouvelobs.com/monde/fusillade-d-orlando/20160614.OB S2511/orlando-le-terroriste-presume-frequentait-le-club-gay-pulse.html 
co-workers, he expressly displayed aggressive homophobia, which can be interpreted as an attempt to overcompensate for his unwanted sexual preferences.

With these seven myths, relationships towards death at the time of radical engagement are not the same. Indeed, believers in the Mother Teresa, Sleeping Beauty, and ISIS as Utopia myths do not wish for death when they are about to leave the country. Lancelot and Zeus believers appear to have accepted the idea of dying as a possible outcome of the fighting they wish to partake in for different motives. The will to die does appear as an objective for believers in the Savior and Fortress myths when religious rituals do not contain them enough. It is, however, important to add that no matter what the initial motive for engagement is, all these youths eventually get to the stage where death appears to be their unique way of existing "for the cause" once the ideology has taken over the whole of their psyche and identity (the last stage of the radicalization process) [40].

In parallel to these seven myths, we identified an intersecting sub-group of youths who may show suicidal tendencies prior to their radical engagement. These possibly suicidal youths are characterized as wavering between several motives for engagement. This hesitation is in itself characteristic of this category of young person. Regardless of the latter, the implicit motive may be the wish to commit suicide, which finds a suitable setting in radical engagement. Indeed, radical Islam rhetoric provides them with a suicide scenario of "where, when, and how?" which characterizes their acute suicidal crisis, with the additional possibility of giving meaning to their deaths and the promise of better lives in the hereafter. A young woman belonging to this subgroup thus called being offered a suicide bomber vest "an opportunity." The youths working with CPDSI who match this profile became aware of their will to die and put it into words when they became de-radicalized.

We can add that an economical factor facilitates the engagement in all the motives, without being determinant, in the core of our French sample. None of the motives is directly based on this economical factor, for French youths.

\section{Discussion on Disengagement and De-radicalization}

We use the term "disengagement" to talk about the youth who parts with the jihadist group which he had previously trusted [41]. We use the term "de-radicalization" to talk about the youth who parts with the ideology in which only divine law can save the world from corruption.

Our experience with 809 young people started from the individual, their experience, their indoctrination, and their engagement, whose logic we have deconstructed and whose form we have made visible. Then, through interactive questioning, we assisted the young people in finding for themselves the flaws in their former thinking, so that they may start building a new framework compatible with the rest of society.

Based on the observation that the jihadist discourse manipulates emotions so as to make the person feel insecure and prime them for radicalization, we decided to also use feelings to reassure our charges during the first stage of combatting the relational indoctrination. Much like the jihadist discourse, the first step of our experimentation consisted of using emotions in order to affect cognitive processes. The anxiety-inducing jihadist discourse has provoked a disaffiliation of the individual by placing them in a substitute community and giving them the illusion of belonging to a protective, sacred, and mythical filiation (which we will refer to as "relational indoctrination"). Working with the parents, we started off by invoking the original bond between them and their child as the principal tool in rebuilding their lives. This has enabled the young people to return to their filial relationships so that they could rediscover part of their affective, cognitive and memory-related points of reference. The goal was to bring the young people back to a time in which they felt safe, i.e., before falling into jihadist anxiety-inducing emotions. To achieve this, the parents (or the spouses) re-staged various "trifles of daily life," a priori mundane routines, which provoked a totally unconscious and reflexive emotional recall in their child (or spouse) by making them remember something from their past that was not affected by the indoctrination. This staging of "remembrance from early childhood" (called "Madeleine de Proust" by the affected families) creates favorable conditions for the emergence of emotions by referencing elements anchored in long-term memory (autobiographical memory). This emotional perception linked to childhood memories may thus be uncontrollable. Indeed, parents report that their children "collapse" and cry when they touch them through a smell, a piece of music, or a gesture that belongs to their set of early childhood memories.

The "jihadist" discourse first dilutes the individual within the paranoid collective. It attempts to numb the individual sensations, and to cut the young person off from the surrounding culture in order to prohibit them from experiencing pleasure. Therefore, remembering micro-events from early childhood triggers not only a resurgence of temporarily suppressed feelings, but also and above all, sensations, which bring them back in body, mind, and spirit. When the youth has such sensations again, he becomes a singular individual again, a subject reincarnated into a body. The dehumanization that the jihadists seek requires disincarnation. De-radicalization requires reincarnation. These memories have an effect on emotions and, as a consequence, work against relational indoctrination (which had facilitated the youth's support for his new group), by allowing the radicalized person to revisit the indelible sensations of his childhood which had not been affected by the radical group. We also succeed in making him feel things so that they are differentiated from what he felt with the radical group. This recall opens a breach in the rigid 
psychological working of the radicalized youth by making him re-live a destabilizing emotional experience because it allows him to remember the reassuring period when he trusted adults. By coming back to his early childhood, we unsettle him because, for a few moments, he is made to feel safe by those whom he perceives-since his radicalization - as dangerous individuals.

Starting from the fact that jihadist ideology (according to which only divine law can save the world from corruption) could assert such authority over the youth to the extent of provoking a true cognitive lock against all other types of thoughts, we sought to weaken the certitudes inherent to ideological indoctrination by introducing doubt in the new thought pattern that the youth was led to adopt. With the help of reformed jihadis, ${ }^{10}$ this step pitches "alternative solutions" to the radicalized person in order to soften the rigidity of his cognition and create a "cognitive opening", defined as the process through which the person becomes more receptive to new ideas and worldviews [42-44]. We attempted to create a breach in the rigidity of the youth's beliefs by confronting him with new information to provoke the recognition of inconsistencies between the goal advertised by the jihadist group and the reality of its actions. The youth is thus cornered into confronting the inconsistencies that do not correspond to his initial motivation (such as helping war victims, for example). Deep down, the youth understands that he must adjust his engagement so that it is not inconsistent with his initial motivation.

This part of our method relies on the initial observation that "jihadist" ideology is constructed in resonance with the motives and ideals of each person. The objective of the "jihadist" discourse is to keep the youth away from the real world in order to put him in a permanent illusion. The youth takes a global view of the jihadist ideology when he finds himself faced with information that is not consistent with the initial ideas that he was presented with of jihadist actions and objectives. Their discourse had authority, because the youth was looking for an answer to his existential questions, and he felt immersed in a sort of consistency between his needs (psychological, social and political) and his involvement with jihadism. Thus, it was necessary to lead him to becoming aware of the discrepancy between the myth pitched by his recruiters (for example, rebuilding the world by possessing the Truth), his personal motive (for example, to finally be useful or to help other Muslims) and the real consequence of the ideology (becoming an accomplice to the extermination of all who do not think like them). It is when fissures emerge in this double consistency with the help of reformed jihadis' testimonies that the radicalized person can start a long retrospective analysis of their doubts, which will lead them out of radicalism.

This technique requires identifying beforehand the

10 The term "reformed jihadi" is not used here as a judicial notion. A reformed jihadi is an individual who previously participated in the jihadist ideology or who went onsite, and who agrees to relate his own experiences in order to disindoctrinate other youths so that they do not live what he did. particular personal motivations (helping Syrians, creating a world of justice, defending Islam, etc.) in order to then place these motivations in front of the contradictions that radical engagement brings (there's no humanitarian work carried out by ISIS; only those who swear allegiance benefit from free heating; they do not apply the basic rules of Islam, etc.). In this regard, our approach displays similarities with the techniques of motivational interviewing [45], which uses amplification of inconsistencies to accompany change. The cognitive re-mobilization only works if the inconsistencies impact one of the personal motivations of the radicalized person. If the reformed jihadi points out an inconsistency not linked to a motivation of the radicalized person, or that is general and abstract (for example, he can see that the jihadist lies when they say the end of the world is near because they ask women to have children to make future soldiers), it does not affect the radicalized person. In order for the radicalized person to start thinking again, he must be destabilized personally by the elements reported by the reformed jihadi and realize himself the inconsistencies between his ideal, his initial motive for engagement and the myth that was pitched to him by the recruiters, and then between the myth and what really happens on the ground. It is the radicalized person himself who must be led to set out arguments starting from the elements reported by the reformed jihadis in order to become aware of the discrepancy between what was promised to him and reality.

These two steps of the experimentation have led to the disengagement of $86 \%$ of the youths we took charge of. In other words, 700 young people have renounced their group. However, we consider only $43 \%$ as de-radicalized [46] that is, having renounced the conviction that only divine law can fight the corruption of the world. Numerous youths denounce the false propaganda and actions of their former jihadist group (whether it is ISIS or Fatah Al Nosra or other), but still dream of a world where "the true Islam" would be applied. From our point of view, they remain weakened by this belief because they might join a new group who would persuade them that this time, they really will enforce "the true Islam". In other words, they have not yet let go of the belief in their utopia, although they call into question particular ways of getting there.

\section{Conclusions}

Our experience with the disengagement and de-radicalization of 809 young people also enabled us to assess how effectively the jihadist discourse interplayed with the motivations and life events of the young person. In other words, we studied the individualization of the propaganda discourse adapted to the individual's desires and their profile. This has proven fundamental in understanding the reasons for engaging in the jihadist discourse so as to come up with a personalized de-radicalization approach [47]. This supports prior work [48] which demonstrated that the success of the 
disengagement program depends not only on assessing how dangerous the recruit is, but also on examining his life. The individualization of the radicalization leads to the individualization of the de-radicalization.

The wide range of motivations for joining a jihadist group means that the problem affects young people of various profiles and backgrounds, even if their common features are their age (12-28) and some vulnerability (psychological or social) when exposed to the recruiter's pitch. In France, we were surprised to find out that almost as many girls as boys $(40 \%)$ got hooked, and as many non-Muslims $(48 \%)$ as Muslims [49].

The limits of this study reside in the waiting of the result after crossing the characteristics of the youths' trajectories and their engagement motives, in order to identify recurrent models. These are only observations at the moment, but this is a first step to show that the psychological impact of ISIS is as strong as its military impact: jihadists do not simply wage war but above all try to turn the individual into an emotional wreck, and to shake the reference points of the collective civilization. We will not defeat ISIS with bombs alone. We cannot rescue kids and others from ISIS's ideology if we do not start from a full understanding of both the motivations of the recruits and the methods employed by the recruiters.

Disengagement and de-radicalization policies, as well as prevention and detection policies, would be more effective if the conceptual framework for this problem were well-defined. For the time being, the programs in France are everything but effective because politicians and researchers cannot agree on what aspects of this problem to address. While some say that radical ideas are not a social issue as long as they do not lead to terrorist acts, others believe that to tackle terrorist acts, one must address the underlying ideology. This explains why assessing the detection and de-radicalization programs leads to controversies among intellectuals and politicians, each trying to reduce the complexity of the jihadist process to their own domain expertise. Yet, just like the "ISIS strategists", we should adopt a cross-disciplinary approach so as to arrive at efficiency and coherence among the different actors involved.

Based on our experiments, we concluded that most de-radicalization models in France and elsewhere stem from the hypothesis that ideology plays a crucial role in the indoctrination of young extremists. Assuming that jihadists have adopted an erroneous version of Islam, these programs [50] have invested in religious scholars who present themselves as being knowledgeable about Islam. As for de-radicalization models that take into account the psychological and emotional dimension, these generally ignore the ideological dimension, thereby using already existing prevention frameworks for drug addiction, delinquency and sectarian drift $[51,52]$.

Our experiences have taught us that de-radicalization programs and studies have not sufficiently explored the link between the emotional dimension and the ideological dimension. This might be due to the fact that observers haven't had access to "the small steps in the life" of the recruit, nor to his "invisible threads" and "implicit motives." Only $31 \%$ of the world's research on terrorism has been able to use empirical data [53]. Even if empirical data has been used, it often comes from testimonies of former jihadists after edited by journalists [54]. However, numerous experts consider the relationships established among the radicalized individuals essential $[55,56]$.

By studying our data, we became aware of the fact that the rejection of "the Other" and of Western democracies is caused simultaneously by both the ideology and the emotional anxiety-inducing approach of the jihadists. All young people that we studied have experienced some sort of obsessive anxiety about everything related to the human experience that was conveyed to and shared with the group, while supporting an ideology according to which everything related to the human experience is tantamount to betraying the oneness of God. It is the mixture of ideology and strong emotional reactions that, from our point of view, causes violence.

This also means that the cognitive opening of the radicalized is dependent on relating the emotional approach to the ideological approach. Even if the radicalization process is based on ideology that provides a binary worldview, one cannot challenge it with knowledge and reasoning [57]. It is counterproductive to directly confront the youth since this will automatically make them suspicious towards anyone outside the radical group. Furthermore, prior work shows that the counter-narrative itself does not achieve much $[58,59]$. The goal is to challenge the cognitive aspect. However, the cognitive approach is not possible without the emotional approach. This validates our hypothesis that as the jihadist discourse combines emotion and ideology in their approach to gain supporters, the actors who want to fight against this phenomenon must also adopt this two-fold approach.

To sum up, to successfully combat the ideology and the jihadist group, the conceptual framework for the disengagement program must integrate this two-fold emotional-ideological dimension.

\section{REFERENCES}

[1] Bézénech, M. \& Estano, N. (2016). A la recherche d'une âme : psychopathologie de la radicalisation et du terrorisme. Annales médico-psychologiques 2016. $174 \quad$ (4), http://dx.doi.org/10.1016/j.amp.2016.01.001.

[2] Fekih-Romdhane F, Chennoufi L, Cheour M. (2015). Les terroristes suicidaires: qui sont-ils? Ann Med Psychol; 174 (4):274-9, http://dx.doi.org/10.1016/j.amp.2015.10.026.

[3] Kacou A. Five arguments on the rationality of suicide terrorist. Aggress Violent Beh 2013; 18(5): 539-47. 
[4] Lankford A. (2010). Do suicide terrorists exhibit clinically suicidal risk factors? A review of initial evidence and call for future research. Aggress Violent Beh; 15: 334-40

[5] Gill P. (2012). Terrorist violence and the contextual, facilitative and causal qualities of group-based behaviors. Aggress Violent Beh; 17: 565-74.

[6] Loza W. (2007). The psychology of extremism and terrorism: A Middle-Eastern perspective. Aggress Violent Beh; 12(2):141-55

[7] Moghaddam FM. (2005). The staircase to terrorism: a psychological exploration. Am Psychol; 60:161-9.

[8] Orbach, B. (2001). Usama Bin Laden and Al-Qaida: Origins and doctrines. Middle East Review of International Affairs, 5, 54-68. IN Loza, W. (2007).

[9] Beck AT. (2002). Prisoners of hate. Beh Res Ther; 40 (3); 209-16.

[10] Gill, p. Horgan, J; \& Deckert, P (2014). Bombing Alone: Tracing the Motivations and Antecedent Behaviors of Lone-Actor Terrorists. Journal of Forensic Sciences, 59(2), 425-435. Retrieved from

http://onlinelibrary.wiley.com/doi/10.1111/1556-4029.12312/ full

[11] Sageman, M. (2007). Radicalization of global Islamist terrorists. Testimony to the US Senate Homeland Security and Governmental Affairs Committee.

[12] Zammit, A. (2010). Who becomes a jihadist in Australia? A comparative analysis. Understanding Terrorism from an Australian Perspective: Radicalisation, De-radicalisation and Counter Radicalisation (Melbourne, Monash University Caulfield Campus, 2010), 1-21. Retrieved from http://artsoline.monash.edu.au/radicalisation/files/2013/03/co nference-2010-who-jihadist-australia-az.pdf

[13] Gill et al. (2014). Ibid.

[14] Zammit, (2010). Ibid.

[15] McCauley \& Moskalenko, S. (2010). Individual and Group Mechanisms of Radicalization. In S. Canna (Ed.), Protecting the Homeland from international and Domestic Terrorism Threats: Current Multi-Disciplinary Perspectives on Root Causes, the Role of Ideology, and Programs for Counter-radicalization and Disengagement. Tropical strategic Multi-layer assessment (SMA), Multi-agency and Air Force research laboratory multi-disciplinary, White papers in support of counter.

[16] Pope C, Mays N. (1995). Reaching the parts other methods cannot reach: an introduction to qualitative methods in health and health services research. BrMed J; 311:42-5.

[17] Bouzar, D., (2006). Quelle éducation face au radicalisme religieux? Ed Dunod.

[18] Horgan, J. (2008). From Profiles to Pathways and Roots to Routes: Perspectives from Psychology on Radicalization into Terrorism. Annals of the American Academy of Political and Social Science, 618 (Article Type: research-article/Issue Title: Terrorism: What the Next President Will Face/Full publication date: Jul., 2008/Copyright 2008 American Academy of Political and Social Science), 80-94.

http:doi.org/10.2307/40375777
[19] Scott, A. Terroristes en quête de compassion, in Cerveau et Psycho, 2015, $\mathrm{N}^{\circ} 11$.

[20] Scott, A. 2015, Ibid.

[21] This feeling can be found both among the 809 "pro-jihadists" that we followed, and among the young pietistic Salafists who were referred to us either directly by their parents or by the law enforcements agencies to ensure they wouldn't turn to violence: Bouzar, D., Bilan 2015,

http://www.cpdsi.fr/wpcontent/uploads/2016/03/rapportactivi te annuel-2015 CPDSI.pdf

[22] Sageman, M. (2007), Ibid.

[23] Bouzar, D., Bilan 2015, Ibid.

[24] Scott, A. 2015, Ibid.

[25] Bronner, G., (2009). La Pensée extreme: Comment des hommes ordinaires deviennent des fanatiques, Denoël.

[26] Jennifer A. Whitson, Adam D. Galinsky and Aaron Kay, (2015). "The Emotional Roots of Conspiratorial Perceptions, System Justification, and Belief in the Paranormal", Journal of Experimental Social Psychology, vol. 56, p. 89-95.

[27] Lillian Reuman, Ryan J. Jacoby, Laura E. Fabricant, Breanna Herring et Jonathan S. Abramowitz, "Uncertainty as an Anxiety Cue at High and Low Levels of Threats", Journal of Behavior Therapy and Experimental Psychiatry, vol. 47, p. 111-119.

[28] Richard S. Lazarus et Suzan Folkman, Stress, Appraisal and Coping, New York (N. Y.), Springer, 1984, cited by Marilou Bruchon-Schweitzer et Robert Dantzer, Introduction à la psychologie de la santé, PUF, 1994.

[29] Bouzar, D. \& Martin M. (2016). Méthode expérimentale de déradicalisation: quelles stratégies émotionnelles et cognitives? Revue Pouvoir, Edition du Seuil, 2016.

[30] Initial indicators of rupture suggested to the French government to detect youths related to jihadist recruits can be found in our report "La métamorphose opérée chez le jeune par les nouveaux discours terrorists" available onlinehttp://www.bouzar-expertises.fr/publications/526-la-me tamorphose-operee-chez-le-jeune-par-les-nouveaux-discoursterroristes, that was further used by the government on their own website Stop-Djihadisme.

[31] Bouzar, D. \& Benyettou, F. (2017). Mon djihad - Itinéraire d'un repenti, éditions Autrement: "While one can worship only one deity (Allah), Muslims also worship other deities without realizing it. For instance, football fans do not deny God but place their favorite player at the same level as God. We explain to you that while worshipping God, only one God, you're not immune to doing things that would be put at the same level as Him. So you're never safe. You have to be afraid"

[32] Bouzar D. \& Martin M. (2016). Pour quels motifs les jeunes s'engagent-ils dans le djihad? Revue Neuropsychiatrie de l'enfant et de l'adolescent, 2016. http://dx.doi.org/10.1016/j.neurenf.2016.08.002.

[33] Bouzar, D. Bilan 2015, Ibid.

[34] Bouzar D. Monsieur Islam n'existe pas, Pour une désislamisation des débats, Hachette Littératures, 2004. 
[35] Scott, A. 2015, Ibid.

[36] Bouzar, D. Bilan 2015, Ibid.

[37] Bouzar, D. 2006, Ibid.

[38] Benslama F. (2016). Un furieux désir de sacrifice, Le surmusulman, Editions du Seuil.

[39] Bouzar D. \& Martin M., 2016, Ibid.

[40] http://www.cpdsi.fr/radicalisation/

[41] Schmid, A. P. (2013). Radicalisation, de-radicalisation, counter-radicalisation: A conceptual discussion and litérature review. ICCT

Research Paper, 97. Retrieved from http://www.academia.edu /download/31064974/ICCT-Schmid-Radicalisation-De-Radic alisation-Counter-Radicalisation-March-2013.pdf

[42] Wiktorowicz, Q., (2004). Joining the cause: Al-Muhajiroun and radical Islam. Syracuse: Institute for National Security and Counterterrorism (INSCT).

[43] Wiktorowicz, Q., (2005). A genealogy of radical Islam. Studies in Conflict and Terrorism, 28 (2), 75-97.

[44] Wiktorowicz, Q., (2006). Anatomy of the Salafi movement. Studies in Conflict and Terrorism, 29 (3), 207-240.

[45] William R. Miller et Stephen Rollnick, L'entretien motivationnel, Aider la personne à engager le changement, 2ème éd., Paris, InterEditions, 2013.

[46] Bouzar, D. (2015).Bilan CPDSI 2015.

[47] Bouzar D. \& Martin M., 2016, Ibid.

[48] Koran, J. (2016). European CVE Strategies from a Practitioner's Perspective. The Annals of the American Academy of Political and Social Science, 668(1), 180-197.

[49] http://www.ladepeche.fr/article/2016/04/27/2333702-numerovert-anti-jihad-nombre-signalements-forte-hausse-depuis-an.h tml We also learned from this inquiry that in 1 out of 5 cases, the call concerned a minor. On the other hand, $61 \%$ of the reported cases were about men, most aged 26 or older. $39 \%$ were women, who were much younger - most aged between 18 (at least) and 25 . Finally, $48 \%$ of the people were converts. Every day, on average 8 alerting cases bounce back to the ministry, and $10 \%$ of the calls alert against a departure to Syria.

[50] The Saudi Arabia model is described in El-Said, H. (2015), New approaches to Countering Terrorism: Designing and Evaluating Counter Radicalization and De-Radicalization Programs. London: Palgrave Macmillan. The Singapore model and its rehabilitation program is described in Briggs, $\mathrm{R}$. (2014). Policy Briefing: De-radicalisation and Disengagement. London: Institute for Strategic Dialogue.

[51] CIPC. (2017). 6ème Rapport international sur la prévention de la radicalisation violente: une étude internationale sur les enjeux de l'intervention et des intervenants. Montréal, Canada: Centre International de Prévention de la Criminalité.

[52] http://www.lagazettedescommunes.com/490888/prevention-d e-la-radicalisation-muriel-domenach-repond-aux-polemiques/

[53] Silke, A. (2001). The devil you know: Continuing problems with research on terrorism. Terrorism and political violence, 13(4), 1-14.

[54] Roy, O. (2016). Le djihad et la mort, Seuil.

[55] Sageman, M. \& Hoffman, B. (2008, a). Leaderless Jihad: terror networks in the twenty-first century. Foreign Affairs, 87(3), 133-138. Retrieved from http://search.proquest.com/docview/36897831 ?accountid $=20$ 032730

[56] Taarnby, M. (2005). Recruitment of Islamist terrorists in Europe. Trends and perspectives.

[57] Bouzar, D. (2015). Comment sortir de l'emprise djihadiste? Editions de l'Atelier.

[58] Bouzar, D. (2015). Ibid.

[59] CIPC. (2017). 6ème Rapport international sur la prévention de la radicalisation violente. Ibid. 